\title{
The catbird seat of the sales force: How sales force integration leads to new product success
}

DOI:

10.1016/j.jiresmar.2016.08.008

\section{Document Version}

Accepted author manuscript

Link to publication record in Manchester Research Explorer

\section{Citation for published version (APA):}

Homburg, C., Kuester, S., \& Andreas, H. (2017). The catbird seat of the sales force: How sales force integration leads to new product success. International Journal of Research in Marketing, 34(2), 462-479.

https://doi.org/10.1016/j.jiresmar.2016.08.008

\section{Published in:}

International Journal of Research in Marketing

\section{Citing this paper}

Please note that where the full-text provided on Manchester Research Explorer is the Author Accepted Manuscript or Proof version this may differ from the final Published version. If citing, it is advised that you check and use the publisher's definitive version.

\section{General rights}

Copyright and moral rights for the publications made accessible in the Research Explorer are retained by the authors and/or other copyright owners and it is a condition of accessing publications that users recognise and abide by the legal requirements associated with these rights.

\section{Takedown policy}

If you believe that this document breaches copyright please refer to the University of Manchester's Takedown Procedures [http://man.ac.uk/04Y6Bo] or contact uml.scholarlycommunications@manchester.ac.uk providing relevant details, so we can investigate your claim.

\section{OPEN ACCESS}




\title{
The catbird seat of the sales force:
}

\section{How sales force integration leads to new product success}

\begin{abstract}
Spanning the boundary between the organization and external market participants, the sales force is in an advantaged position to garner unique market insights. At the same time the sales force has a pivotal role in bringing new products to the market as vendors following their own adoption. The present study reunites the literature that has previously considered the sales force either in their role as facilitators of market insights or as vendors of new products by proposing a mediating effects framework that explicitly examines the sales force in their dual role. Data collected from 609 firms provide evidence that the utilization of the sales force's insights for new product development, referred to as sales force integration, engenders new product success. The authors focus in particular on the examination of the input-output transformation process by studying multiple mediation paths through which sales force integration brings about new product success via new product advantages and sales force new product adoption. The effectiveness of sales force integration is highly contingent upon factors including information quality, timing, non-monetary sales force incentives, innovation degree, and competitive intensity. This study discusses how managers should act to fully benefit from the impact of sales force integration on new product success.
\end{abstract}

Keywords: Sales force integration - Boundary spanner - Multiple mediation - New product advantage Sales force adoption - New product success 


\section{Introduction}

Previous studies acknowledge the effectiveness of market information processing activities in contributing to higher new product success rates (Ozkaya et al. 2015; Li and Calantone 1998). This line of research recognizes the integration of market insights from external stakeholders (e.g., customers, suppliers) and internal stakeholders (e.g., marketing, research and development) as a key success factor in new product development (NPD) (Gruner and Homburg 2000; Olson et al. 2001). The sales force has been proposed as an internal stakeholder group contributing to market intelligence but previous research has largely neglected the sales force in this role (Ahearne, Rapp, Hughes, and Jindal 2010a; Ernst, Hoyer, and Rübsaamen 2010).

This lack of attention is surprising especially since the sales force can provide specific insights with respect to customer needs and competitive activities (Ernst et al. 2010; Le Bon and Merunka 2006). These insights are attributable to the frontline operations of salespeople and their direct interactions with market participants, which allow them to absorb unique market information that extends beyond the knowledge of other internal functions (Liao and Chuang 2004). The sales department thus harbors boundary people (Thietart and Vivas 1981) in an advantaged position to obtain valuable market intelligence. As such, the sales force is in a catbird seat for gathering external information, which can be leveraged internally to create new products that are better aligned with customer needs and that provide product advantages in the eyes of customers, enhance customers' new product adoption and, ultimately, new product success.

Incorporating these market insights into NPD may also promote the sales force's own new product adoption behavior and motivate its role as vendors of new products that reflect their own input. Sales force new product adoption has been identified as a motivational factor and is defined as the salespeople's acceptance of a new product and the internalization of its goals (i.e., commitment), as well as the extent to which they work hard and smartly to achieve these goals to make the new product successful (i.e., effort) 
(Hultink and Atuahene-Gima 2000). In fact, the sales force has been viewed as an internal customer whose adoption can critically impact new product success (Wieseke, Homburg, and Lee 2008).

We argue that including the sales force's market intelligence in NPD may thus positively impact new product success via its own adoption behavior and should complement the effect on new product success via the external constituent 'customer'. Hence, the intensity with which the market insights generated by the sales force are accounted for internally in the scope of NPD processes, which we define as sales force integration, may have favorable effects on the success of new products via these two separate routes. The objective of the present study is to scrutinize how sales force integration engenders new product success, i.e., the degree to which the new product achieves the corporate objectives which are associated with the new product project (Gatignon and Xuereb 1997) via these two routes.

There is a dichotomy in the literature on how the sales force facilitates firms' new product endeavors. One strand of this literature considers the sales force's role as vendors and adopters in the new product context. This research identifies the sales force as a key driver in new product adoption (Atuahene-Gima 1997; Beuk et al. 2014; Hultink and Atuahene-Gima 2000). Ahearne et al. (2010a) also consider salespeople's role as vendors and posit that the effort that salespeople allocate to new products is determined by the extent to which they believe in the value of the product and the resulting effort affects customer perceptions of new products and thus sales. Wieseke et al. (2008) find that the brand adoption of sales managers and subordinate salespeople is influenced by expected customer demand, i.e., their evaluations of brand attributes. It is a key tenet of our research that the sales force serves as market intelligence gatherer and that integrating this knowledge in NPD can influence the attributes of products, the sales force's own adoption, and finally innovation success which represents a perspective lacking in these previous studies.

Another strand of literature acknowledges this role of the sales force as providers of market insights for NPD. Kuester and Rauch (2016) demonstrate that R\&D's use of market intelligence provided by sales positively influences innovation performance and show that NPD depends on sales to systematically generate 
market insights. Ernst et al. (2010) also investigate sales as a source of market information for NPD in the context of cross-functional cooperations with marketing and R\&D. The authors identify a positive influence of sales-marketing and sales-R\&D cooperation on NPD project performance and propose the conjoint integration of know-how from sales, marketing, and R\&D as direct antecedents of NPD project performance.

In summary, while prior research has considered the sales force either as vendors of new products or as facilitators of market insights no study has investigated the impact of the sales force in their dual role. Thus prior research has failed to ascertain how market insights provided by the boundary spanning sales force potentially impacts new product success by creating products that are better aligned with customer needs and by motivating the sales force's own adoption behavior. We close this research gap by developing a multiple mediating effects framework with an external mediation path, via the customer as the external constituent, and an internal mediation path, via the constituent sales force as the 'internal customer'. This framework acknowledges the dual role of the sales force as facilitators of market insights and vendors of new products that were developed using their insights. We also account for the uncertainty impacting the effectiveness of this framework by examining contingency factors, such as the quality of the information gathered, the point in time during NPD when the integration occurs, non-monetary sales force incentives, whether radical or incremental products are concerned, and the market's competitive intensity.

With evidence garnered from three datasets, two of which are at the product level $\left(n_{1}=219 ; n_{2}=121\right)$ and one at the overall corporate level $\left(n_{3}=269\right)$, and additional objective data we offer several contributions to the existing literature. First, the present study hones our understanding of the unique role of the sales force in the realm of NPD as a major source of unique know-how that can be leveraged to support the development of successful new products. Second, our multiple mediating effects framework explicitly examines the dual paths by which the sales force impacts new product success by being facilitators of market insights that are uniquely valuable for NPD and by delivering new products to the market following their own adoption when selling products that were developed based on their own market insights. Third, the 
consideration of contingency factors identifies important situational conditions impacting the effectiveness of sales force integration. Fourth, we discuss what companies can do to enable the sales force in their organizations and to fully benefit from the impact of sales force integration on new product success.

\section{Theoretical foundations and hypotheses development}

\subsection{The knowledge-based view of the firm}

The knowledge-based view of the firm (KBV) serves as our theoretical foundation. The KBV considers knowledge as the company's primary and most important strategic resource which determines its competitive advantages and long-term success (Felin and Hesterly 2007; Grant 1996a). Knowledge is acquired and harbored by individuals within the organization and the firm's fundamental role is to integrate this knowledge (Grant 1996b). Thus, not the knowledge per se is important but firms' ability to integrate this knowledge in order to develop superior new products that succeed in the marketplace (De Luca and Atuahene-Gima 2007).

As boundary spanners, salespeople can provide complementary and valuable insights with respect to customer needs and competitive activities (Ernst et al. 2010). According to the KBV's logic the sales force's knowledge is not important by itself but the firm's ability to incorporate it internally to improve effectiveness and efficiency. For example, when a salesperson knows that a certain customer segment particularly values certain functionalities in a product, benefits can only accrue from this insight, when it is accounted for in NPD. In this sense, we propose that sales force integration serves as an important mechanism that incorporates the knowledge of the sales force in NPD in order to create successful new products.

\subsection{Conceptual framework and hypotheses development}

Our conceptual framework (see Figure 1) investigates two mediation paths through which sales force integration potentially exerts an impact on new product success. Additionally, we posit a positive relationship 
between new product advantages and sales force new product adoption and explore conditions under which sales force integration is more or less effective.

2.2.1. The mediating role of new product advantages in the sales force integration-new product success relationship

New product advantages refer to the superior benefits that customers obtain from a firm's new product that cannot be found in competing products (Cooper and Kleinschmidt 1987). Research shows that companies that consider customer and competitor information are more likely to achieve relative advantages for their resulting new products. Atuahene-Gima (1996), for example, finds a positive relationship between firms' market information processing capabilities and new product advantages. Li and Calantone (1998) provide evidence that the acquisition, interdepartmental sharing, and integration of customer and competitor knowledge exert a positive effect on new products' competitive superiority. Based on these results, we argue that the integration of sales force information induces the development of new products that create superior value from a customer perspective (Atuahene-Gima 1996; Grant 1996a). This reasoning is in line with the KBV, which considers knowledge a critical resource and its integration within the company as a major prerequisite for success. In this sense, sales force integration serves as such a mechanism for incorporating the sales force's knowledge in NPD.

The literature on innovation success factors has consistently identified new product advantage as a key determinant of new product success (Henard and Szymanski 2001; Song and Parry 1997). It is argued that customers are more prone to purchase new products when these products offer features that better meet their needs and provide benefits that cannot be found in competitive products (Rogers 2003). These products are more likely to be adopted by customers and are, therefore, more likely to be successful in the marketplace (Maidique and Zirger 1983). We expect that the utilization of sales force insights leads to the development of new products that better reflect customer needs previously identified by the sales force which creates product advantages and positively affects customer adoption and ultimately new product success. 


\section{Figure 1}

Conceptual model

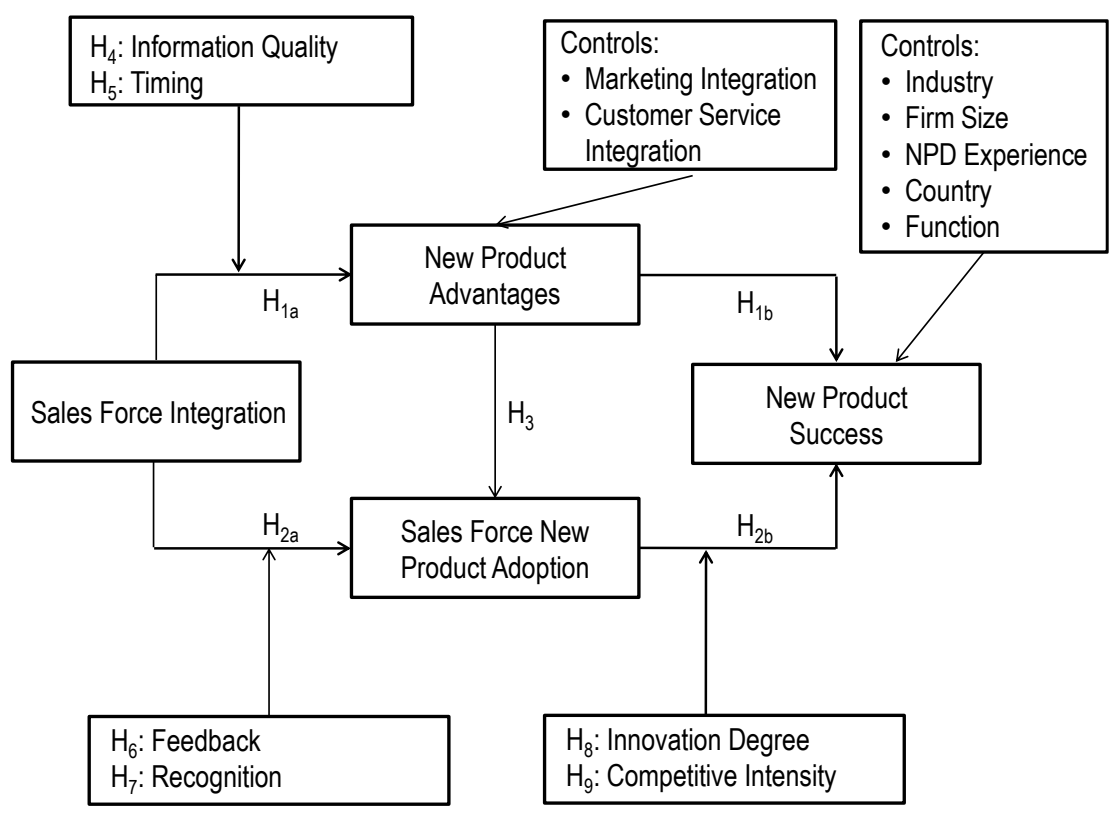

This expectation is consistent with the KBV, which considers the link between product-based competitive advantages and success as a logical consequence emanating from the integration of firm-internal knowledge sources (Grant 1996a). Thus, we hypothesize our first mediation path:

H1: New product advantage mediates the relationship between sales force integration and new product success in such a way that the greater the sales force integration, the greater the new product advantages (H1a) and the greater the new product success $(\mathrm{H} 1 \mathrm{~b})$.

\subsubsection{The mediating role of sales force new product adoption in the sales force integration-new product} success relationship

Most studies on new product adoption have focused on customer adoption behavior and have largely neglected the adoption behavior of salespeople (Wieseke et al. 2008). Given the decisive role of salespeople in bringing new products to the market (Ernst et al. 2010) and their possible dysfunctional behavior resulting from new product rejection (Atuahene-Gima 1997; Wotruba and Rochford 1995), there is a particular need to identify means to facilitate the adoption of new products by salespeople. 
Past research has considered a firm's commitment to innovation to be a predominant factor determining employee behavior including their new product adoption (Scott and Bruce 1994). In our view, sales force integration represents a form of company commitment as a firm's use of sales force information for NPD sends a clear signal that the information retrieval of salespeople is valued. Such signal encourages sales force new product adoption for several reasons. First, salespeople feel more confident in selling new products that have experienced higher levels of company commitment and support (Atuahene-Gima 1997). Second, sales force integration leads to the development of products that reflect the customer needs previously identified by the sales force which will act as a motivational factor in selling encounters. According to expectancy theory and previous research, this motivational impact should increase the sales force's efforts devoted to new product success (Nroom 1964; Wieseke et al. 2008). Furthermore, sales force adoption is supported when salespeople are empowered by identifying and internalizing the goals of the new product (Hultink and Atuahene-Gima 2000). In having provided input for the new product this identification and internalization is likely to be fortified. Thus, we expect sales force integration to play a crucial role in facilitating the adoption of a new product by the sales force.

Drawing on the KBV, we regard sales force new product adoption as a source of competitive advantage that assists firms in achieving new product success. This argument is based on the notion that salespeople represent a first line of customers whose personal level of new product adoption largely determines their behavior and performance concerning a new product (Ahearne et al. 2010a; Atuahene-Gima 1997). In support of this view, previous studies indicate that highly committed salespeople devote more effort to achieving new product-related goals, and these increased efforts support selling performances, timely market launches, and rapid diffusion of new products in the market (Ahearne et al. 2010a; Hultink and Atuahene-Gima 2000). In this regard, the sales force new product adoption serves as an important indicator of market success (Wieseke et al. 2008). Thus, we hypothesize our second mediation path: 
H2: Sales force new product adoption mediates the relationship between sales force integration and new product success in such a way that the greater the sales force integration, the greater the sales force new product adoption $(\mathrm{H} 2 \mathrm{a})$ and the greater the new product success $(\mathrm{H} 2 \mathrm{~b})$.

\subsubsection{The relationship between new product advantages and sales force new product adoption}

We additionally propose that sales force new product adoption is directly influenced by new product advantages. Following the reasoning of Wieseke et al. (2008) we expect that the sales force evaluates a new product from a customer's perspective. According to expectancy theory (Vroom 1964) an individual's motivation to exert more effort in a given task situation will depend on the individual's expectation 1) that the effort will result in a desired level of performance and 2) that this performance will produce a desired outcome. We argue that salespeople who perceive the new product to be superior in the eyes of customers will expect that their increased selling effort for the new product will improve their selling performance and ultimately customers' new product adoption. In fact, we propose that the sales force's expectancy beliefstates about their force and their ability to perform (Nroom 1964) are impacted by the fact that their own market intelligence was used in NPD. Thus, we expect a higher likelihood of sales force new product adoption when the sales force relates the innovation to high levels of new product advantages.

H3: New product advantages are positively related to sales force new product adoption.

\subsubsection{Moderating hypotheses}

The adoption processes described are surrounded by uncertainty and we consider contingency factors that influence the effectiveness of sales force integration by reducing this uncertainty. We scrutinize information quality and timing of sales force integration within the NPD process as potential moderators of the sales force integration-new product advantage relationship. We also investigate the non-monetary incentives of sales force feedback and recognition as potential moderators of the sales force integration-sales force new product adoption relationship. Prior research suggests that the impact of new product adoption by the sales force on new product success may vary due to adoption barriers and other influencing factors 
introducing uncertainty in this relationship (Anderson and Robertson 1995). In this regard, we explore a new product's innovation degree and competitive intensity as important moderators generating uncertainty. Information quality - NPD processes are characterized by high levels of uncertainty (Hoeffler 2003). For example, ambiguity exists with regard to the quality standards that new products need to meet or with regard to their market potential (Montaguti, Kuester, and Robertson 2002). Information quality, defined as the degree to which the market insights provided by the sales force are valuable and directly useful for the development of new products (Zimmer, Henry, and Butler 2007), is particularly relevant to help reduce uncertainty inherent in NPD. To reduce these uncertainties, managers of NPD projects need to engage in the processing of high-quality information that is unbiased, accurate, relevant, and directly useful for a specific task (Maltz and Kohli 1996). Unclear and irrelevant information may increase uncertainty (Zimmer et al. 2007) which, in turn, can lead to the development of new products that fail to deliver superior benefits to customers (Dowling and Staelin 1994). Reducing uncertainty through a sufficient level of information quality should constitute an important condition positively impacting the relationship between sales force integration and new product advantages. For example, Hultink et al. (2011) find that information acquisition and use are associated with NPD performance under conditions of high information quality. Thus, we expect that higher levels of information quality strengthen the relationship between sales force integration and new product advantages and we posit:

H4: The relationship between sales force integration and new product advantages is stronger for higher levels of information quality provided by the sales force.

Timing - Timing refers to the intensity with which sales force integration occurs in the various NPD phases of predevelopment, development, and commercialization. The examination of timing builds on the argument that the various phases of the NPD process exhibit different levels of uncertainty (Olson et al. 2001) and that sales force information is thus not equally effective across all phases (Olson et al. 2001). 
Salespeople's unique knowledge about customer needs and competitor activities can help to reduce uncertainties especially when this know-how is utilized in early NPD phases (Le Bon and Merunka 2006; Liao and Chuang 2004). Removing uncertainty in the early phase of the NPD process should be particularly effective because this phase exhibits a higher degree of uncertainty compared to the other stages (Troy et al. 2008; Veldhuizen, Hultink, and Griffin 2006). In later phases, there will be less need to reduce uncertainty because decisions have already been made as to which product ideas are pursued and how (Kim and Wilemon 2002). We thus consider sales force integration to be most effective in the predevelopment stage for the generation of new product concepts (Zahay, Griffin, and Fredericks 2004) as compared to later stages. We hypothesize:

H5: The relationship between sales force integration and new product advantages is stronger when more intense sales force integration occurs in the predevelopment stage of the NPD process as opposed to the later stages of this process.

Sales force feedback on how their market insights were used for NPD - In our study, we consider sales force feedback as a non-monetary incentive which refers to the extent to which the firm provides feedback to salespeople on how their market insights were used in NPD. In the literature, feedback is considered as the information provided to salespeople regarding the results they are expected to attain and how well they are performing in relation to these expectations (Jaworski and Kohli 1991). Feedback thus has an informational function (regarding which activities to emphasize) and a motivational function (as positive feedback represents a reward) (Jaworski and Kohli 1991). Providing the sales force with feedback on how their market insights were used in NPD should strengthen the effect of sales force integration on sales force adoption. As argued before, sales force integration is a form of company commitment because a firm's use of sales force information for NPD sends a clear signal to salespeople that providing market insights is valued. Salespeople feel more confident in selling new products that have experienced these higher levels of company commitment (Atuahene-Gima 1997). By providing salespeople with explicit feedback on how their 
market insights were used for NPD, the motivational effects emanating from sales force integration should be enhanced. Additionally, the informational function of this feedback may lower uncertainties that the sales force potentially perceives with regard to the role they are expected to fulfill. Kuester and Rauch (2016) found that uncertainty about others' expectations with regard to gathering market insights can create role ambiguity. This ambiguity can hamper salespeople's effectiveness and we expect that this uncertainty will also negatively affect the motivational impact of sales force integration on sales force new product adoption. Feedback that the salesforce is expected to collect and share information for NPD should therefore impact this relationship positively. Thus, we posit:

H6: The relationship between sales force integration and sales force new product adoption is stronger for higher levels of sales force feedback on how their market insights were used for NPD.

Sales force recognition for providing market insights for NPD - Sales force recognition represents another form of non-monetary sales force incentive and is defined as a "formal periodic acknowledgement of performance accomplishments of individual salespeople" (Wotruba, Macfie, and Colletti 1991, p. 9). Recognition has positive motivational effects on salespeople (Apasu 1987). Also, recognition should reduce the uncertainty that the salesforce potentially perceives with regard to the gathering of market insights when they are in the field. In our context, sales force recognition refers to the extent to which the sales force was especially recognized for their efforts in providing market insights for the purpose of NPD. In line with our discussion of sales force feedback, sales force recognition should represent a motivational condition under which the impact of sales force integration on sales force adoption should be especially pronounced. $\mathrm{H7}$ : The relationship between sales force integration and sales force new product adoption is stronger for higher levels of sales force recognition for providing market insights for NPD.

Innovation degree - Innovation degree reflects a product's level of innovativeness from a company or market perspective on a spectrum between marginally innovative and highly innovative products (Hoeffler 2003). The latter generally evoke higher levels of uncertainty as perceived by customers and increased 
adoption resistance (Veryzer 1998). Communication with customers has been proposed as a strategy to overcome new product adoption resistance (Castaño, Sujan, Kacker, and Sujan 2008; Lee and O'Connor 2003). Salespeople usually engage in communications with customers and provide information that can ease customer anxieties, facilitate new product adoption, and support favorable new product performance outcomes (Chandy, Tellis, Maclnnis, and Thaivanich 2001; Lee and O'Connor 2003). Research has demonstrated that the successful management and reduction of uncertainties through customer education are more important for radical new products (Castaño et al. 2008; Hoeffler 2003). Specifically, Castaño et al. (2008) find that the efficacy of uncertainty reduction through communication is especially given when more innovative products are concerned. Because the adoption of new products by the sales force serves as an important indicator of the new product's acceptance in the marketplace (Wieseke et al. 2008) and thus reduces uncertainty surrounding the new product, the effect of sales force adoption on new product success should be especially effective when selling more innovative new products. We thus hypothesize: H8: The relationship between sales force new product adoption and new product success is stronger for new products with higher innovation degrees.

Competitive intensity - Customer resistance to new product adoption is likely to increase in markets that are characterized by high levels of competitive intensity, which refers to the extent and aggressiveness of competitive activities in a product's target market (Jaworski and Kohli 1993; Kumar, Subramanian, and Yauger 1998). This higher likelihood of resistance is due to customers' ability to choose from a wider range of competing product offerings in markets in which many suppliers must exert significant efforts to attract customers (Kumar et al. 1998). In this sense, competitive environments introduce uncertainty for the sales force to place new products in the market. As a consequence, the commitment of salespeople toward an innovation and their efforts to convince customers of the new product's benefits should be more important in engendering new product success. Research shows that salespeople perceive their job of selling new products as more challenging and more intrinsically rewarding in highly competitive environments, and 
such perceptions should increase their persuasive power and selling performance (Atuahene-Gima 1997; Hultink and Atuahene-Gima 2000). It has been argued that the sales force may enjoy these challenging environments and thus perform better (Atuahene-Gima and Michael 1998). The intrinsic appeal and challenging nature of selling in competitive environments should have a reinforcing effect on the sales force adoption-new product success relationship. Building on these arguments, we hypothesize:

H9: The relationship between sales force new product adoption and new product success is stronger for higher levels of competitive intensity.

\section{Data and method}

\subsection{Data collection and sample}

To obtain our data, we developed an online survey that targeted competent and qualified managers as key informants who have been personally involved in the NPD processes of their firms within the last three years. Only respondents who indicated that they were highly experienced with at least one recently completed new product project and who occupied an influential management-level position qualified for the study. In the survey, we asked respondents to select a new product that was developed and introduced by their respective companies within that time period. To make recall easier for respondents, we requested that managers refer to the development of a typical new product at their companies. The recollection of a broader topic is recommended to enhance recall before more specific questions are posed. To ask for a typical (and not a particular, say, successful product) is also intended to minimize respondents' tendency to answer in a way they think the researchers want them to respond (Podsakoff et al. 2003).

Using a commercial database, we contacted 1,215 managers in the US, the UK, and Australia. The final sample size yielded 219 usable questionnaires and an effective response rate of $18.0 \%$. Respondents represented various functions (24.5\% product manager, $23.9 \%$ general manager, $14.1 \%$ production manager, $13.6 \%$ marketing manager, $15.7 \%$ R\&D/innovation manager, $8.2 \%$ sales manager) and a broad range of 
industries (53.9\% B2B firms, 46.1\% B2C firms). On average, respondents had worked for 12.05 years in their positions and had been involved in 5.74 NPD projects.

\subsection{Measures}

The latent constructs of our model were measured reflectively by seven-point Likert scales. The questionnaire was pretested with 44 managers to verify the understandability, completeness, and structure of the survey and the measurement quality of indicators. The measurements are summarized in the Appendix.

Sales force integration was measured to capture the intensity with which market insights of the sales function are used within a firm's process to develop the specific new product the respondents referred to. Given the scarcity of scales measuring the integration of firm-internal stakeholders, the items were developed based on the customer integration literature (Gruner and Homburg 2000). New product success measures refer to the achievement of internally communicated goals associated with the new product project (Gatignon and Xuereb 1997; Wei and Morgan 2004). We followed the approach of Cooper and Kleinschmidt (1987) for the assessment of new product advantages. Sales force new product adoption was conceptualized as a two-dimensional construct consisting of the attitudinal dimension of "commitment" and the behavioral dimension of "effort" (cf. Atuahene-Gima 1997). The measurement scale of Zimmer et al. (2007) served as the basis for assessing information quality. The construct of timing was gauged for the three NPD process phases of predevelopment, development, and commercialization (Veldhuizen et al. 2006). We followed the approach of Le Bon and Merunka (2006) for measuring sales force feedback and sales force recognition. Innovation degree was measured reflecting a product's degree of innovativeness from a company/market perspective, ranging from marginally innovative to highly innovative (Atuahene-Gima 1995). Competitive intensity was measured in accordance with Jaworski and Kohli (1993).

Several control variables were considered in our analysis. With industry and firm size (number of employees working in the company as an average over the last three years), we included two control variables that have previously been regarded in the literature as potential determinants of new product success (e.g., 
Baker and Sinkula 1999; De Luca and Atuahene-Gima 2007). As an extension of learning theory, we also expect a manager's level of experience with NPD projects to affect the success of new products. We therefore incorporated NPD experience as a control variable that was assessed by the number of NPD projects the respondents have actively been involved in over the past three years. We also accounted for the fact that we collected data in different countries (country) and surveyed respondents with various functional backgrounds (function). Lastly, to identify the differential impact of sales force integration on new product advantage we controlled for the intensity with which the market insights provided by the marketing function (marketing integration) and by the customer service function (customer service integration) were utilized within the development process of the new product the respondents referred to. These measurements were in analogy with our measurement of sales force integration.

\section{Data analysis and results}

\subsection{Measurement validation}

We performed confirmatory factor analysis (CFA) using the Analysis of Moments of Structures (AMOS) software package (Version 22) to assess the reliability, validity, and unidimensionality of our latent constructs (Anderson and Gerbing 1988). The results of the measurement model demonstrate a very good fit to the data $\left(\mathrm{X}^{2} / \mathrm{df}=1.78 ; \mathrm{RMSEA}=.060 ; \mathrm{IFI}=.96 ; \mathrm{CFI}=.95 ; \mathrm{TLI}=.93 ; \mathrm{NFI}=.90\right)$. The reliability measures (Cronbach's alpha, composite reliability, and average variance extracted) reveal very good results for all constructs (see Appendix). Following Stine (1995), we also assessed multicollinearity by calculating variance inflation factors (VIF) of the explanatory variables. The VIF values range between 1.02 and 3.85 , indicating that multicollinearity does not present a major problem (see Table 1). The convergent validity of the measurement scales is supported because all of the factor loadings are highly significant (Anderson and Gerbing 1988). We also support discriminant validity among the constructs by testing the Fornell-Larcker criterion (Fornell and Larcker 1981). 


\subsection{Tests for non-response and common method bias}

We assessed a possible non-response bias in our data by comparing early and late respondents (Armstrong and Overton 1977). Basically, we treated the late respondents as non-respondents following recommendations made in the literature (Collier and Bienstock 2007). This extrapolation technique is based on the assumption that late respondents are most similar to non-respondents because their replies took a longer time to obtain. For this analysis, response time was measured as the time between sending and receiving the survey and we compared construct means for the first quarter to the construct means of the last quarter of the sample on this variable (Armstrong and Overton 1977; Collier and Bienstock 2007). This assessment did not reveal significant differences in construct means indicating that non-response bias does not seem to pose a serious problem. Furthermore, we conducted several tests to assess whether common method bias exists in our data set. We conducted the Harman single-factor test, the single commonmethod-factor test (Podsakoff et al. 2003), and the marker variable technique (Lindell and Whitney 2001). These tests reveal that common method bias does not distort our findings.

\subsection{Test of main effects}

Based on the data garnered from our 219 managers, we tested our conceptual model with AMOS. This model included all constructs from our conceptual framework and the control variables explaining $73.6 \%$ of the variance in new product success. Our analysis reveals a positive and significant relationship between sales force integration and new product advantages $(B=.488 ; p<.01)$, which in turn positively affects new product success ( $\beta=.718 ; p<.01)$. Sales force integration also exerts a significant and positive effect on sales force new product adoption ( $B=.609 ; p<.01)$, which positively impacts new product success ( $\beta=$ $.176 ; p<.01)$. These findings support $\mathrm{H} 1 \mathrm{a}, \mathrm{H} 1 \mathrm{~b}, \mathrm{H} 2 \mathrm{a}$ and $\mathrm{H} 2 \mathrm{~b}$. In addition, we find a direct, positive relationship between new product advantages and sales force new product adoption $(B=.416 ; p<.01)$, in support of H3. Table 2 reports these results and the fit indices. 
Table 1

Correlation matrix

\begin{tabular}{|c|c|c|c|c|c|c|c|c|c|c|c|c|c|c|c|c|c|}
\hline & & 1 & 2 & 3 & 4 & 5 & 6 & 7 & 8 & 9 & 10 & 11 & 12 & 13 & 14 & 15 & 16 \\
\hline 1. & $\begin{array}{l}\text { Sales force inte- } \\
\text { gration }\end{array}$ & 1 & & & & & & & & & & & & & & & \\
\hline 2. & $\begin{array}{l}\text { New product ad- } \\
\text { vantages }\end{array}$ & .45 & 1 & & & & & & & & & & & & & & \\
\hline 3. & $\begin{array}{l}\text { Sales force new } \\
\text { product adoption }\end{array}$ & .74 & .61 & 1 & & & & & & & & & & & & & \\
\hline 4. & $\begin{array}{l}\text { New product suc- } \\
\text { cess }\end{array}$ & .45 & .78 & .59 & 1 & & & & & & & & & & & & \\
\hline 5. & $\begin{array}{l}\text { Information qual- } \\
\text { ity }\end{array}$ & .69 & .62 & .72 & .60 & 1 & & & & & & & & & & & \\
\hline 6. & $\begin{array}{l}\text { Timing - Prede- } \\
\text { velopment }\end{array}$ & .51 & .33 & .44 & .36 & .47 & 1 & & & & & & & & & & \\
\hline 7. & $\begin{array}{l}\text { Timing - Develop- } \\
\text { ment }\end{array}$ & .41 & .27 & .44 & .34 & .38 & .48 & 1 & & & & & & & & & \\
\hline 8. & $\begin{array}{l}\text { Timing - Com- } \\
\text { mercialization }\end{array}$ & .33 & .29 & .38 & .33 & .34 & .50 & .42 & 1 & & & & & & & & \\
\hline 9. & $\begin{array}{l}\text { Sales force feed- } \\
\text { back }\end{array}$ & .74 & .47 & .69 & .45 & .64 & .44 & .47 & .37 & 1 & & & & & & & \\
\hline 10. & $\begin{array}{l}\text { Sales force recog- } \\
\text { nition }\end{array}$ & .64 & .49 & .71 & .48 & .65 & .37 & .37 & .23 & .64 & 1 & & & & & & \\
\hline 11. & Innovation degree & .05 & .24 & .11 & .19 & 12 & .03 & .16 & .08 & .03 & .16 & 1 & & & & & \\
\hline 12. & $\begin{array}{l}\text { Competitive inten- } \\
\text { sity }\end{array}$ & .46 & .30 & .37 & .27 & .40 & .27 & .22 & .24 & .39 & .28 & -.07 & 1 & & & & \\
\hline 13. & Firm size & .01 & .00 & .00 & -.06 & .03 & .03 & .05 & .00 & .03 & .03 & -.02 & .00 & 1 & & & \\
\hline 14. & NPD experience & .15 & .07 & .12 & .07 & .14 & .10 & .09 & .18 & .14 & .06 & .07 & -.03 & .01 & 1 & & \\
\hline 15. & $\begin{array}{l}\text { Marketing integra- } \\
\text { tion }\end{array}$ & .10 & .08 & .13 & .09 & .01 & .07 & .11 & .20 & .13 & .11 & .04 & .05 & -.09 & .06 & 1 & \\
\hline \multirow[t]{4}{*}{16.} & $\begin{array}{l}\text { Customer service } \\
\text { integration }\end{array}$ & .23 & .14 & .26 & .16 & .17 & .03 & .12 & .09 & .22 & .18 & .00 & .08 & -.06 & .14 & .24 & 1 \\
\hline & Mean & 5.26 & 5.63 & 5.53 & 5.67 & 5.53 & 4.16 & 3.90 & 4.11 & 5.36 & 5.15 & 4.42 & 5.35 & $\begin{array}{l}4410.19 \\
\text { No. employ- } \\
\text { ees }\end{array}$ & $\begin{array}{c}12.04 \\
\text { Years work } \\
\text { experience }\end{array}$ & 4.87 & 5.21 \\
\hline & $S D$ & 1.19 & 1.11 & 1.12 & 1.10 & 1.11 & 2.40 & 2.51 & 2.63 & 1.17 & 1.44 & 1.42 & 1.19 & 16887.09 & 7.38 & 1.84 & 1.83 \\
\hline & VIF (Maximum) & 3.52 & 2.01 & 3.85 & -- & 3.04 & 1.79 & 1.60 & 1.58 & 2.84 & 2.52 & 1.15 & 1.39 & 1.02 & 1.10 & 1.16 & 1.19 \\
\hline
\end{tabular}

$\mathrm{n}=219$; VIF Variance Inflation Factor $\left[=1 /\left(1-\mathrm{R}^{2}\right)\right]$ (Stine 1995) 
To test whether new product advantages and sales force new product adoption mediate the relationship between sales force integration and new product success, we analyzed the multiple mediation following Preacher and Hayes (2008) by performing a bootstrap procedure in AMOS with a resample size of 5,000 to calculate bias-corrected confidence intervals. This type of analysis is recommended to discern the influence of the two mediator variables that could otherwise be obscured in traditional mediation analyses.

This test produces a significant indirect effect of new product advantages (99\% Cl: .24; .46) and a nonsignificant direct effect of sales force integration on new product success $(p=.80)$. In support of our mediating effect in $\mathrm{H} 1$, we confirm the predicted role of new product advantages as a full mediator of the sales force integration-new product success relationship. Furthermore, the analysis yields a significant indirect effect of sales force new product adoption $(95 \% \mathrm{Cl}: .00 ; .50)$. The direct effect of sales force integration on new product success is equally not significant $(p=.99)$, supporting the predicted role of sales force new product adoption as fully mediating the effect of sales force integration on new product success, confirming our mediating effect in $\mathrm{H} 2$ (see Table 3).

With regard to industry, firm size, NPD experience, country, and function, we do not find a significant relationship between any of these controls and new product success. Interestingly, the effects of marketing integration ( $B=.059 ; p>$.1) and customer service integration $(B=.127 ; p>1$ ) on new product advantages are not significant. Additionally, our control variables do not contribute significantly to a further explanation of new product advantages $\left(\Delta R^{2}=.004\right)$ and new product success $\left(\Delta R^{2}=.005\right)$.

In summary, these results lend strong support to the effectiveness of sales force integration as an important driver of new product success. 
Table 2

Test of mediating effects and moderating effects (main sample, product-level data) ${ }^{+}$)

\begin{tabular}{|c|c|c|c|c|}
\hline Hypothesis & Independent variable & Dependent variable & Beta & t-value \\
\hline $\mathrm{H} 1 \mathrm{a}$ & Sales force integration & New product advantagesa & $.488^{* * *}$ & 6.696 \\
\hline $\mathrm{H} 1 \mathrm{~b}$ & New product advantages & New product success ${ }^{b}$ & $.718^{* * *}$ & 9.335 \\
\hline $\mathrm{H} 2 \mathrm{a}$ & Sales force integration & Sales force new product adoptionc & $.609^{* * *}$ & 11.337 \\
\hline $\mathrm{H} 2 \mathrm{~b}$ & Sales force new product adoption & New product success & $.176^{* * *}$ & 2.616 \\
\hline H3 & New product advantages & Sales force new product adoption & $.416^{* * *}$ & 7.852 \\
\hline Hypothesis & Moderator variable & Dependent variable & Beta & $t$-value \\
\hline $\mathrm{H} 4$ & Sales force integration $\mathrm{x}$ Information quality & New product advantages & $.209^{* * *}$ & 3.497 \\
\hline \multirow[t]{3}{*}{ H5 } & Sales force integration x Timing (Predevelopment) & New product advantages & $.104^{* *}$ & 2.005 \\
\hline & Sales force integration x Timing (Development) & New product advantages & .015 & .298 \\
\hline & Sales force integration $x$ Timing (Commercialization) & New product advantages & $-.195^{* * *}$ & 3.846 \\
\hline $\mathrm{H} 6$ & Sales force integration $x$ Sales force feedback & Sales force new product adoption & $.107^{* *}$ & 2.201 \\
\hline $\mathrm{H} 7$ & Sales force integration x Sales force recognition & Sales force new product adoption & $.140^{\star * \star}$ & 2.814 \\
\hline $\mathrm{H} 8$ & Sales force new product adoption $\mathrm{x}$ Innovation degree & New product success & $.093^{* *}$ & 2.233 \\
\hline $\mathrm{H} 9$ & Sales force new product adoption $x$ Competitive intensity & New product success & $.081^{* *}$ & 1.939 \\
\hline
\end{tabular}

$\mathrm{a}^{2}=.230 ;{ }^{\mathrm{b}} \mathrm{R}^{2}=.736 ;{ }^{\mathrm{c}} \mathrm{R}^{2}=.785$

$\mathrm{X}^{2} / \mathrm{df}=1.78 ; \mathrm{RMSEA}=.060 ; \mathrm{IFI}=.96 ; \mathrm{CFI}=.95 ; \mathrm{TLI}=.93 ; \mathrm{NFI}=.90$

${ }^{* * *} p<.01,{ }^{* *} p<.05,{ }^{*} p<.1$

$\mathrm{n}_{1}=219$

+) Due to uneven sample sizes in the different country settings, assessment of measurement invariance via multi-sample confirmatory factor analysis (Steenkamp and Baumgartner 1998) was not feasible. To check whether measures can be used cross-nationally, we excluded the responses from Australia and the UK and re-ran all analyses with the USsample only. Results were robust in magnitude and significance levels against this change so that we conclude that cross-national invariance is given in our study. 


\section{Figure 2}

Results of moderated regression slope analysis

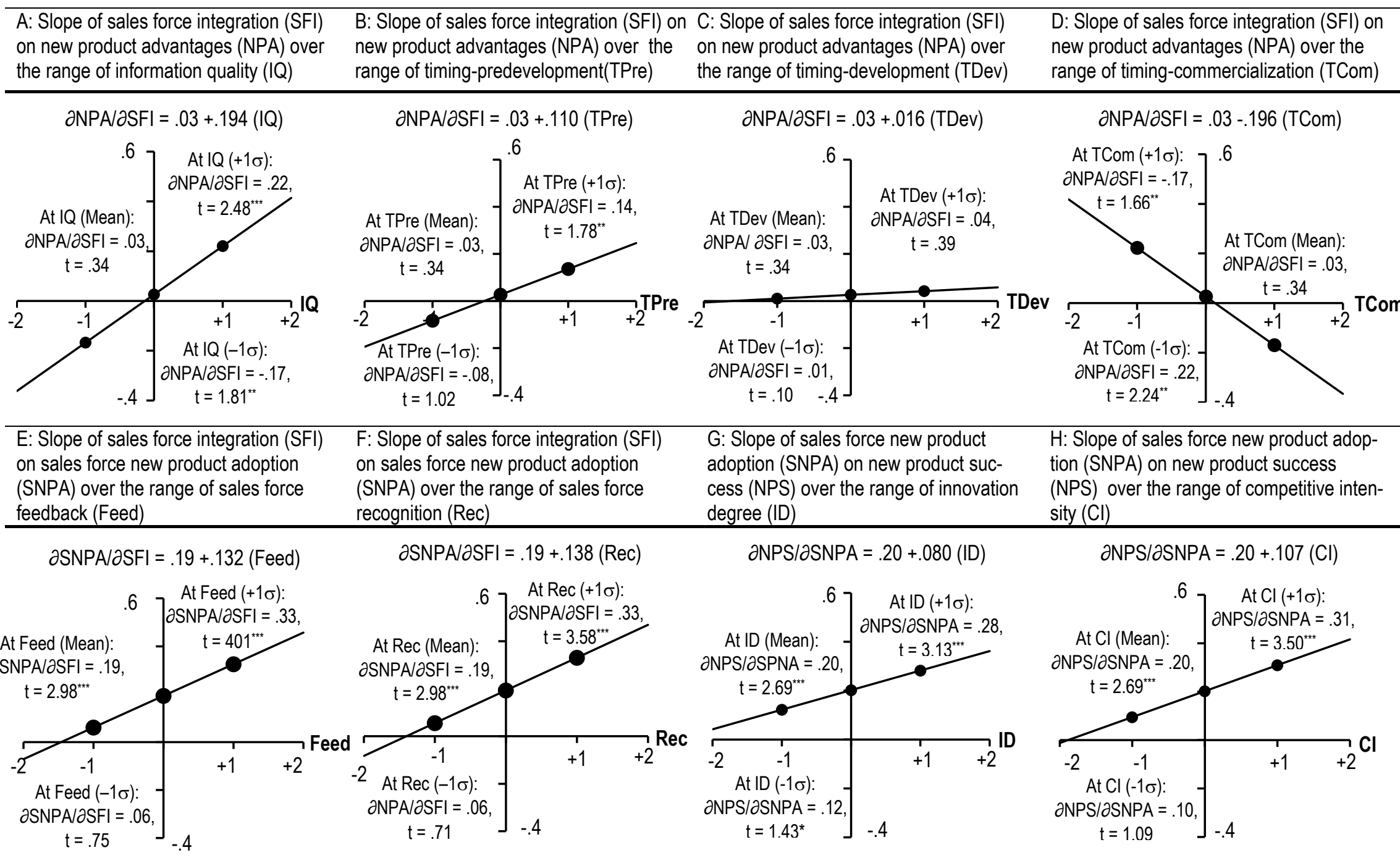

${ }^{* * *} p<.01,{ }^{* *} p<.05,{ }^{*} p<.1 ; n_{1}=219$ 


\section{Table 3}

Multiple mediation analysis

\begin{tabular}{cccc}
\hline $\begin{array}{c}\text { Relationship } \\
\begin{array}{c}\text { Independent variable - Me- } \\
\text { diator - Dependent variable) }\end{array}\end{array}$ & $\begin{array}{c}\text { Direct Effect } \\
\text { (SFI - NPS) } \\
\text { without mediator }\end{array}$ & $\begin{array}{c}\text { Direct Effect } \\
\text { (SFI - NPS) } \\
\text { with mediator }\end{array}$ & $\begin{array}{c}\text { Indirect effect } \\
\text { (SFI - Mediator - NPS) } \\
\text { via mediator }\end{array}$ \\
\hline SFI - NPA - NPS & $.491^{* * *}$ & $.021^{\text {ns }}$ & $.339^{* * *}$ \\
SFI - SNPA - NPS & $.491^{* * *}$ & $.001^{\text {ns }}$ & $.220^{* *}$ \\
${ }^{* * * *} p<.01,{ }^{* *} p<.05,{ }^{*} p<.1$ & \\
SFI = Sales force integration; NPA = New product advantages \\
SNPA = Sales force new product adoption; NPS = New product success
\end{tabular}

\subsection{Test of moderating effects}

To test our proposed moderating effects, we created interaction terms by the case-wise multiplication of the underlying standardized construct scores for the predictor and moderator variables. Both the moderating latent variable and the interaction term were then included in AMOS. We find that higher levels of information quality strengthen the positive relationship between sales force integration and new product advantages $(H 4)(B=.209 ; p<.01)$. Our results demonstrate the importance of an early, intense integration of the market information provided by salespeople in the NPD process (H5). Specifically, we find that high levels of sales force integration in the predevelopment stage significantly strengthen the effect on new product advantages $(B=.104 ; p<.05)$. Interestingly, the moderating effect of timing is insignificant if sales force information is considered in the development stage $(B=.015 ; p>.1)$, whereas high intensities of sales force integration in the commercialization stage even exert a significantly negative moderating influence on new product advantages $(B=-.195 ; p<.01)$.

In addition, the results show that both sales force feedback $(\mathrm{H} 6)(B=.107 ; p<.05)$ and sales force recognition $(H 7)(B=.140 ; p<.01)$ both significantly and positively impact the relationship between sales force integration and sales force new product adoption. We find that the link between sales force new product adoption and new product success is stronger for more radical new products $(B=.093 ; p<.05)(\mathrm{H} 8)$. 
Lastly, high levels of competitive intensity strengthen the relationship between sales force new product adoption and new product success $(\mathrm{H} 9)(\beta=.081 ; p<.05)$ (see Table 2$)$.

To further explore the impact of our contingent effects, we conducted regression analyses with interaction terms to analyze moderated regression slopes. The plots and the significance tests for the slopes are shown in Figure 2, Panel A-H. These results clearly support the significant impact of our moderators as important contingency factors.

\subsection{Further validation analyses}

\subsubsection{Testing for endogeneity due to simultaneity}

It is conceivable that the path running from sales force new product adoption to new product success suffers from reverse causality. In the case of reverse causality, our independent variable sales force new product adoption would be caused by the dependent variable new product success and thus produces simultaneity. To assess the influence of the putative cause of new product success on sales force new product adoption, we conducted an experiment with salespeople. We recruited 156 salespeople from a commercial panel to conduct a two group posttest-only randomized experiment for assessing whether new product success determines actual sales force new product adoption behavior. Respondents were randomly assigned to two experimental groups resulting in equal cell sizes. On average, the salespeople had worked for their respective company 12.71 years and in their current position in sales for 8.53 years.

We asked the salesperson to envision that they work as a salesperson selling a portfolio of products in a given market and informed them that their company had introduced a new product. Then, we manipulated new product success by stating that it had become evident that the product was turning out to be a success/failure in the market (treatment group/control group). After exposing the groups to these scenarios, we measured sales force new product adoption as before (see Appendix). Finally, participants responded to manipulation checks and questions related to demographics. 
We checked whether the scenarios were understood as intended ('The product is turning out to be a success'; $\mathrm{MNPS}_{\mathrm{NP}}=1.87, \mathrm{M}_{\mathrm{noNPS}}=5.35, \mathrm{p}<.01 ;$ with $1=$ strongly agree, $7=$ strongly disagree) and that the respondents regarded the described scenarios as realistic $(M=2.06$; with 1=realistic, $7=$ not realistic at all). We concluded that our manipulations were successful. Our results reveal that the apparent market success respective market failure of the new product has no significant effect on participants' new product adoption behavior as there are no statistically significant differences between group means as determined by oneway ANOVA (MNPA_Success $=3.67$, MSNPA_No_success $=3.11, F(1,155)=1.281 ; p>$.1). Using this experimental setting we can rule out that new product success causes sales force adoption behavior.

We additionally controlled for the validity threat of endogeneity by applying an instrumental-variable approach to further assess the reliability of our study. Specifically, we conducted a two-stage least squares (2SLS) regression, one of the most used methods to ensure the robustness of estimates potentially threatened by endogeneity (Antonakis et al. 2010). To prevent reverse causality, we included in our 2SLS estimation instrumental variables that exert an influence on the dependent variable, which must be significantly and strongly related to the (potential) endogenous predictor (Wooldridge 2012). Moreover, the method requires at least as many instruments as endogenous variables, but more instruments than endogenous variables to test the overidentifying restrictions (Antonakis et al. 2010).

Accordingly, we set the variables sales force integration (I), sales force feedback (m), and sales force recognition (n) as instruments to investigate if there is an endogeneity threat of sales force new product adoption $(\mathrm{x})$ in its relation to new product success $(\mathrm{y})$. All variables are defined and conceptualized as for our conceptual model (see Figure 1). Specifically, sales for integration is defined as the intensity with which the market insights generated by the sales force are accounted for internally in the scope of NPD processes. Sales force feedback refers to the extent to which the firm provides feedback to salespeople on how their market insights were used in NPD. Sales force recognition is defined as formal regular acknowledgements of individual salespeople's achievements with regard to bringing in their market insights for the 
purpose of NPD. New product success refers to the degree to which the new product achieves the corporate objectives which are associated with the new product project.

The 2SLS regression is estimated in two steps using Stata (Version 13.0). The first-stage equation (1) recovers the causal effect of the instruments on sales force new product adoption, defined as the salespeople's acceptance of a new product and the internalization of its goals, as follows:

$$
x_{i}=\gamma_{0}+\gamma_{1} l_{i}+\gamma_{2} m_{i}+\gamma_{1} n_{i}+\sum_{k=1}^{c} \gamma_{k} f_{i k}+u_{i}
$$

The second-stage equation (2) includes the predicted value of sales force new product adoption ( $\dot{x})$ to estimate new product success:

$$
y_{i}=\gamma_{0}+\gamma_{1} \dot{x}_{i}+\sum_{k=1}^{c} \theta_{k} f_{i k}+e_{i}
$$

The results show that the predicted value of the second-stage equation does not correlate with the combined error term. With that in mind, we estimated the proportion of the variance that sales force integration, sales force feedback, and sales force recognition predict in sales force new product adoption in the first-stage equation, which overlaps with new product success from the second-stage equation. The analysis shows a good model fit, robust estimates (Wald $X^{2}=377.66$, Prob $>X^{2}=0.000, R^{2}=0.635$ ) and reliable values of the regressors (z-value of sales force new product adoption: $3.11(P>|z|:$.002); z-value of new product advantages: $10.73(P>|z|: .000)$.

To test the correlation of the error terms $(\mathrm{u})$ and $(\mathrm{e})$ in a further analysis, we applied the Durbin $\mathrm{X}^{2}$ and Wu-Hausman test, which produced non-significant results (Durbin $\mathrm{X}^{2}=.307, \mathrm{p}=.579$; Wu-Hausman $\mathrm{F}(1$, $215)=.302, p=.582)$ (Hausman 1978; Baum, Schaffer, and Stillman 2007). This result implies that the variable sales force new product adoption is not endogenous. We also checked the strength of our instruments in the first-stage regression statistics with regard to the $F$-value and the critical values $(F(3,214)=83.133$, Prob $>F=.000$ ). In summary, the analysis provides evidence for the usage of the selected instruments. We further examine the overidentifying restrictions applying the Sargan and Basmann $x^{2}$ test (Baum et al. 
2007). Both tests yield reliable results $\left(\right.$ Sargan $X^{2}=.101, p=0.950 ;$ Basmann $\left.X^{2}=.099698, p=0.951\right)$ confirming the validity of the instruments and the correct specification of our model.

\subsubsection{Testing for endogeneity due to selection bias}

We invited a heterogeneous group of managers to participate in our study. However, the respondents mainly reveal sales force integration in the case of successful products. These similarities among the respondents could result in a non-randomly selected sample which causes biased estimates. Even though we are concerned with the selection of the product the respondent decided to refer to when answering the questionnaire and not with the selection of respondents into the survey we decided to apply Heckman's two-step method (Heckman 1979, 1976) which treats self-selection as a specification error and controls for this potential bias. The inclusion of a correction factor enables us to estimate the unbiased parameters of less successful products and thus countervails the unilateral characteristics of the surveyed managers.

According to the requirements of the selection method, we first conducted a factor analysis in response to the unobserved latent variables in the Structural Equation Model (SEM) (Steenkamp and Baumgartner 2000). The differentiation between successful and non-successful products is based on a commonly used median split for categorizing information (Sethi and Iqbal 2008). In order to distinguish between the two product success groups, we applied a probit model and computed the inverse Mill's ratio (Puhani 2000) (Stage 1). In Stage 2, we divided our framework in three linear regression models. Model 1 has new product success, Model 2 sales force new product adoption and Model 3 new product advantage as dependent variables. The respective control variables were included in the regressions ${ }^{1}$.

\footnotetext{
${ }^{1}$ Model 1: (new product success) $=\beta_{0}+\beta_{1}{ }^{*}$ (new product advantage $)+\beta_{2}{ }^{*}$ (sales force new product adoption) $+\beta_{3}{ }^{*}$ (firm size) $+\beta_{4}{ }^{*}$ (NPD experience) $+\beta_{5}{ }^{*}$ (industry) $+\beta_{6}{ }^{*}$ (function) $+\beta_{7}{ }^{*}$ (country) + e; Model 2 : (sales force new product adoption) $=\beta_{0}+$ $\beta_{1}{ }^{*}$ (new product advantage) $+\beta_{2}{ }^{*}$ (sales force integration) + e; Model 3: (new product advantage) $=\beta_{0}+\beta_{1}{ }^{*}$ (sales force integration) $+\beta_{2}{ }^{*}$ (marketing integration) $+\beta_{3}{ }^{*}$ customer service integration $+e$.
} 
Entering the Heckman two-step command in Stata leads to a non-significant inverse Mill's ratio and robust results among both product success groups. In particular, the selection model shows an unbiased estimation of the parameter values after correcting for the differences in high and low new product success.

Additionally, we conducted a spotlight analysis (Spiller et al. 2013) by using a mid-scale split (at 4) to distinguish between successful and unsuccessful products and by choosing two different ranges of high and low sales force integration on the basis of a median split. We tested the relation between sales force integration and new product success with respect to particular spotlights (Spiller et al. 2013). The result confirms the underlying theoretical assumptions and provides a high consistency with the outcomes of our other reliability tests.

\subsubsection{Validation of product-level results with additional sampling at product and corporate level}

To validate the results of our framework we collected data from 121 additional managers identified from a commercial panel. We used the same online survey as in our main sample and applied the same procedure and criteria for participation (effective response rate: $24.5 \%)(48.8 \%$ B2B, $51.2 \%$ B2C). We tested our framework by asking these managers about a new product that was developed and introduced by their respective companies within the last three years. As before, we requested that managers refer to the development of a typical new product in their companies. CFA results indicate very good model fit and are supportive of reliability, validity, and unidimensionality of the latent constructs. Also, discriminant validity among all constructs is supported (Fornell and Larcker 1981) and multicollinearity is not an issue.

Our analysis using AMOS shows that the model holds as all main effects are highly significant. Additionally, five out of six moderator hypotheses are positive and significant (information quality, timing, sales force feedback, sales force recognition, and competitive intensity). Only the moderating impact of innovation degree cannot be supported. As in the main study, the effects of marketing integration $(B=.086, p>.1)$ and 
customer service integration ( $B=.093, p<.1)$ on new product advantages are insignificant. Table A1 Section $A$ in the Web Appendix summarizes these results.

Also, we validated our product-level results on the company level by adapting the survey to ask managers not about a typical new product but about all new products that have been developed in their firms within the last three years. We again used an online survey and a manager panel to collect our data applying the same approach and criteria for participation as before $(n=269$; effective response rate: $21.4 \%)$ (52.0\% B2B, 48.0\% B2C). CFA results are supportive of reliability, validity, and unidimensionality of our constructs. The analyses indicate very good model fit, prove discriminant validity, and rule out multicollinearity issues.

Our analysis using AMOS again reveals that all main effects are significant and five out of six moderators are positive and significant (information quality, timing, sales force feedback, sales force recognition, and innovation degree). As before, the effects of marketing integration $(B=.056, p>.1)$ and customer service integration ( $B=.067, p>.1$ ) on new product advantages are insignificant. These results support our project-level findings (see Table A1 Section B in the Web Appendix).

We additionally collected objective financial data for 42 companies (15.6\%) in our corporate-level validation sample by accessing financial databases (e.g., CompuStat) and the firms' annual reports. We substituted our subjective measures of corporate new product success with two objective performance measures - sales volume and total asset value - and recalculated the model. The results demonstrate that our framework remains robust against this change and prove the strong influence that sales force integration has on a company's overall financial performance (see Table A2 in the Web Appendix).

In summary, we conclude that sales force integration is effective for enhancing the success of new products and also supports company-wide new product success. 


\section{Discussion}

The present research provides empirical evidence that incorporating sales force information into NPD processes engenders new product success. We demonstrate the sales force's pivotal role as boundary spanners between the organization and external market players and thereby ascertain sales force integration as a key determining factor of new product success. Our research pinpoints the unique impact that the consideration of salespeople's market insights has in the realm of NPD and it is the first study that sheds light on the mechanisms by which sales force integration exerts its impact on new product success in a sales context.

We find that sales force integration affects new product success via two separate routes. First, the utilization of salespeople's market knowledge in NPD supports firms in developing new products that are better aligned with customer needs and, thus, provide superior benefits in the eyes of customers. These new product advantages favor the adoption of new products by customers, and consequently, lead to higher levels of new product success. With the validation of this first route, our study establishes the fact that the sales force constitutes a unique and valuable knowledge repository that represents a decisive strategic resource and that serves as the basis for the creation of knowledge-based competitive advantages and enhanced company success when integrated internally (Felin and Hesterly 2007; Grant 1996a).

Second, sales force integration positively affects new product success by the adoption of new products by salespeople. The empirical confirmation of this second route indicates that the incorporation of sales force information into NPD increases the confidence of salespeople in selling new products and their motivation to contribute to the success of innovations that reflect their market insights. Although this finding can be explained by expectancy theory, suggesting a strong connection between the beliefs of salespeople in 
the market potential of new products and their behavioral efforts to support the performance of such products (Vroom 1964; Wieseke et al. 2008), prior research suggests quite the opposite effect. Based on institutional economics, Ahearne et al. (2010a) argue that salespeople who believe in a new product's superiority and success will exert less effort to sell the new product based on the conviction that the product will sell itself independently of their efforts and more effort is expended on products that are tough sells. This argument does not hold in the scope of our study for two reasons. First, the sales force's expectancy beliefstates about their force to perform and their ability to perform (Vroom 1964) are impacted by the fact that their own market intelligence was used in NPD. Second, when salespeople observe that their insights are reflected in new products that are ready to market, they have a potent emotional attachment to these new products. This attachment, in turn, serves as an additional encouragement for devoting efforts to a new product and its performance in the market. Given the positive link between the new product adoption by salespeople and new product success, our results clearly point to the sales force as representing a first line of customers whose adoption of the new product largely determines its acceptance in the marketplace.

In this sense, our dual mediating effects framework reunites the literature that represents the sales force either as a facilitator of market insights for the purpose of NPD (Ernst et al. 2010; Kuester and Rauch 2016) or as vendors of new products (Ahearne et al. 2010a; Atuahene-Gima 1997; Beuk et al. 2014; Hultink and Atuahene-Gima 2000; Wieseke et al. 2008). Considering this dual role of the sales force strongly contributes to our understanding of how salespeople can act as a major source of know-how that can be leveraged to support the development of successful new products above and beyond their primary role of selling.

When comparing the effectiveness of sales force integration to the integration of market insights provided by marketing or the customer service department our study clearly discerns that the sales force delivers critical information for NPD. Especially the result with regard to the role of marketing is surprising. While 
other studies argue that marketing can translate consumer needs into product characteristics and thus influence NPD positively (e.g., Drechsler, Natter, and Leeflang 2013; Henard and Szymanski 2001), recent research on the influence of the marketing department is more in line with our finding. In their replication study, Homburg et al. (2015) demonstrate that with regard to NPD, marketing has lost influence while the sales department has gained influence providing evidence of a migration of influence from the marketing department to the sales department. Our research indicates that the sales force seems to be particularly situated in proximity to customers to garner information uniquely supportive of creating superior products. Menguc et al. (2011) also find that the sales department has deep customer knowledge due to their regular interactions with this stakeholder group. The differential effectiveness of sales force integration for NPD in this regard thus pinpoints the important if not critical role that sales can provide to the organization.

Our study reveals that our mediating effects framework is highly contingent upon contextual factors that influence the effectiveness of sales force integration by affecting the uncertainty inherent in the sales force integration-new product success relationship. Referring to the relationship between sales force integration and new product advantages, we demonstrate that sales force integration is only effective if salespeople are able to provide high-quality market insights. Sales force information being low in quality even has adverse effects on new product advantages. This result supports the view that the consideration of sales force information alone does not guarantee success. Rather, insights provided by the sales function must be of sufficient accuracy and relevance to reduce complexities and to support managers in the creation of new products that customers will perceive as superior (Zimmer et al. 2007).

Moreover, phase-specific investigations of the development processes of new products support theoretical considerations and case study findings that highlight the importance of considering customer feedback and competitive activities in the early phases of the NPD process (Gruner and Homburg 2000; Troy et al. 2008). Our results emphasize that market information acquired by salespeople is especially valuable in the predevelopment stage of the NPD process where uncertainties are particularly pronounced. In 
this most information-intensive phase, sales force insights support the identification of product ideas that have the potential to outperform competing product offerings when launched, which substantially reduces the uncertainty of embarking on a wrong NPD endeavor. Conversely, we find that high levels of sales force integration in the latest phase of the NPD process considerably weaken its positive effect on new product advantages. Although sales force integration in the commercialization phase may lead to the pursuit of effective market launch strategies (Ernst et al. 2010), such integration is unlikely to increase customer value perceptions of a new product. This notion is based on the contention that changes in new product designs and features toward the end of the NPD process cannot fully reflect sales force insights because the development phase is already completed and new products are ready to be commercialized.

We also identified a moderating effect of sales force feedback on the sales force integration-sales force new product adoption relationship. Our study demonstrates, that by providing feedback on the use of sales force information in NPD, the motivational effects resulting from salespeople's ability to bring in their market knowledge for the benefit of NPD are enhanced and sales force integration exerts an even greater effect on their own adoption behavior. Similarly, we investigated the effect of sales force recognition. Prior research has shown that recognition has positive motivational effects on salespeople (Apasu 1987; Le Bon and Merunka 2006) and we found that recognition represents a condition under which the impact of sales force integration on sales force new product adoption is especially pronounced. Providing the sales force with feedback on the use of their information in NPD and recognition of their activities as information provider has positive motivational effects and both reinforce the impact of sales force integration on the sales force's own adoption behavior.

With regard to the relationship between sales force new product adoption and new product success, our results reveal that this relationship is stronger for higher levels of a new product's innovation degree. This finding specifically indicates that the effort that salespeople expend on highly innovative products assists in conveying previously unrecognized new product benefits to customers (Ahearne et al. 2010a). As a result, 
customer perceptions of new products improve along with intended and actual adoption behaviors (Smith and Park 1992). This result leads to the conclusion that a company's sales force serves as a valuable communication vehicle that translates customer risk perceptions into recognitions of superior gains derived from new product adoption. Therefore, the sales force assists particularly in supporting the market acceptance of radical innovations, which customers perceive as especially risky (Castaño et al. 2008; Lee and O'Connor 2003). The results from our main study support the moderating effect of competitive intensity, with the impact of salespeople's new product adoption on new product success being strongest for high degrees of competitive intensity. This finding confirms that salespeople's efforts to persuade customers of the value of new products should be more effective in highly competitive markets in which customers can choose from multiple suppliers and salespeople relish the challenge of selling new products (Brown and Peterson 1994). With regard to our rationales regarding product newness and competitive intensity, Frenzen et al. (2010) find that market-related uncertainty enhances the positive effect of delegating price negotiations to the sales force on firm performance. The authors argue that this effect occurs because salespeople have more precise information about their (uncertain) market due to their proximity to customers. This information lead decreases the firm's costs of gathering the information required to reduce uncertainty. The sales force's adaptive behavior in uncertain environments does not only seem to ensure effectiveness of price negotiations but - as in our case - in placing really new products in competitive markets.

\section{Managerial implications}

Our study indicates to managers that sales force integration represents a critical resource that promotes improved new product performance outcomes if it is effectively incorporated in NPD. The implications of the present research are valuable to the understanding of new product success, especially when the focus on customers as adopters is complemented with an understanding of how adoption behavior of the sales force as an 'internal customer' complements customer adoption. We argue that incorporating 
market intelligence provided by the sales force in NPD positively impacts the sales force's own adoption behavior via both a higher emotional commitment and via a stronger effort that the sales force expends to make the new product successful. By allowing the sales force to bring in their knowledge from the field, firms can harness this knowledge resource not only to develop superior new products but also to motivate salespeople's own new product adoption behavior, which should have a reinforcing effect on new product success. Thus, the sales force should be recognized for the dual role they are so apt to fulfill as boundary spanners of the firm. In addition to fulfilling their role of selling products in the market, companies should also emphasize their role in gathering and sharing market insight for the purpose of NPD.

The review of the results of our moderating factors point to several implications for managers. To ensure sales force insights at high quality levels, salespeople should be advised regarding the types of information that are considered useful and relevant for creating superior new product offerings. Effective training on questioning and listening skills may improve their proficiency in providing high-quality information for NPD purposes (Le Bon and Merunka 2006; Sharma and Lambert 1994). Companies should also develop and implement an organizational setting that allows for an effective exchange of the knowledge generated by the sales force between all departments that are involved in NPD. Depending on the organizational structure and the size of the firm, information sharing can be facilitated through regular, scheduled meetings between NPD project members of various functions or efficient reporting systems. Our findings also imply that this cross-functional integration of knowledge should happen rather early than later. Managers of NPD projects should therefore actively attempt to gain and consider sales force information in the early NPD phases in which specific market insights are particularly valuable for the identification of market potential and promising new product concepts.

Managers should also be aware of the fact that feedback to and recognition of the sales force do not only act as motivational factors that reinforce the impact of sales force integration on the sales force's own adoption behavior. Feedback serves an informational function by reminding salespeople which activities to 
emphasize (Jaworski and Kohli 1991). The informational function has previously been identified in providing salespeople with role clarity (Jaworski and Kohli 1991; Miao and Evans 2012) and thus feedback can be used to provide the sales force the transparency that they are expected to engage in information gathering and sharing, potentially reducing role conflict with regard to their main task of selling. Feedback and recognition are non-monetary incentives that also serve a potent motivational function that we show to be effective in incentivizing the sales force to engage in their critical role as information providers for NPD.

Another key implication of this study for managers is that the adoption of new products by salespeople is a strong indicator of new product acceptance by the market. As our study shows, the adoption behavior of salespeople largely depends on the superior benefits these innovations potentially provide for customers. Thus, managers are advised to communicate internally the benefits of innovations and provide training that assists the sales force in gaining a deep appreciation of a firm's new product offerings. Salespeople who internalize crucial advantages of the new product will be more convinced by its acceptance by customers and will, therefore, devote greater efforts to supporting the new product. We recommend that salespeople, in turn, highlight new product benefits when communicating with customers and prospects because improved value perceptions of a new product reduce adoption barriers and increase new product purchases. These communication strategies can be especially effective when new products are highly innovative (Castaño et al. 2008). Companies operating in highly competitive environments will find that new product adoption by the sales force is particularly effective in engendering new product success. The sales force seems to enjoy the challenge of selling in tough environments and should be supported to do so effectively. Their activities can be supported in providing additional information on the competitive landscape and by jointly developing differential benefits and unique value propositions of own product offerings that can be leveraged by the sales force in interactions with customers.

Although we have clearly identified sales force integration as a key driver of new product success, a large number of firms continue to disregard sales force information when developing new products. Thus, 
salespeople are still an underutilized resource of market intelligence that offers companies a great potential for differentiation and we strongly recommend hearing the voice of the sales force when developing new products.

\section{Limitations and suggestions for further research}

Our research design relies on retrospective data from respondents and we are aware of the limitations of memory-based data. It has been recommended to complement memory-based data with data from a different set of respondents and with objective data (Golden 1997). Our analyses have been conducted on different units of analysis, i.e., the product level and the corporate level, and the relationships hold at both levels involving different respondents. We also ran the analysis with objective performance data from a secondary database as dependent variables. The results indicate that the key relationships identified by using the objective performance data hold in direction and magnitude.

Additionally, concerns could be voiced with regard to endogeneity. We ran analyses assessing threats of endogeneity potentially accruing from selection bias and simultaneity. The results of these tests demonstrate the validity of our findings.

For the sake of parsimony and understanding, we constrained our conceptual framework to only key constructs of theoretical importance. Other variables exist that would be of interest for researchers and could enhance the richness of our findings. For example, because salespeople still represent an underutilized resource of market intelligence (Pass et al. 2004) it would be worthwhile to explore sales force integration barriers in future research. One such barrier may be the time and effort that salespeople require to communicate their market insights internally. In this respect, the information retrieval task of the sales force may be seen as conflicting with their primary duty of selling a firm's products (Kuester and Rauch 2016; Le Bon and Merunka 2006). One important question in this regard is the optimal allocation of time for these 
respective activities. The results on sales force feedback and recognition indicate that non-monetary incentives have reinforcing effects of the sales force's information gathering activities on their own adoption behavior. Future research may further explore the role of monetary incentives in this regard.

There is also relative paucity of research addressing sales as a team effort. Sales teams often play prominent roles, especially in business-to-business settings with technologically complex products and services (Ahearne, MacKenzie, Podsakoff, Mathieu, Lam 2010b). A study of group influences of selling teams on industrial salespeople's cross-selling behavior (Schmitz 2013) is the first to examine the effect of group norms on individual salespeople. The author found that the effect of a salesperson's motivation on his or her adoption of the company's product portfolio is stronger when the team has a strong group norm for cross-selling. This finding indicates that group norms, amongst other factors, impact a salesperson's motivation to adopt products. Thus, the impact of social influences in the realm of sales force integration and sales force adoption are fruitful avenues for future research. 


\section{References}

Ahearne, M., Rapp, A., Hughes, D. E., \& Jindal, R. (2010a). Managing sales force product perceptions and control systems in the success of new product introductions. Journal of Marketing Research, 47 (4), 764-776.

Ahearne, M., MacKenzie, S., Podsakoff, P., Mathieu, J., \& Lam, S. (2010b). The role of consensus in sales team performance. Journal of Marketing Research, 47 (3), 458-469.

Anderson, E., \& Robertson, T. S. (1995). Inducing multiline salespeople to adopt house brands. Journal of Marketing, 59 (2), 16-31.

Anderson, J. C., \& Gerbing, D. W. (1988). Structural equation modeling in practice: A review and recommended two step approach. Psychological Bulletin, 103 (3), 411-423.

Antonakis, J., Bendahan, S., Jacquart P., \& Lalive R. (2010). On making causal claims: A review and recommendations. Leadership Quarterly, 21 (6), 1086-1120.

Apasu, Y. (1987). The Importance of Value Structures in the Perception of Rewards by Industrial Salespersons. The Journal of the Academy of Marketing Science, Vol. 15 (1), 1-10.

Armstrong, J. S., \& Overton, T. S. (1977). Estimating nonresponse bias in mail surveys. Journal of Marketing Research, 14 (3), 396-402.

Atuahene-Gima, K. (1995). An exploratory analysis of the impact of market orientation on new product performance. A contingence approach. The Journal of Product Innovation Management, 12 (4), 275- 293.

Atuahene-Gima, K. (1996). Market orientation and innovation. Journal of Business Research, 35, 93-103.

Atuahene-Gima, K. (1997). Adoption of new products by the sales force: The construct, research propositions, and managerial implications. Journal of Product Innovation Management, 14 (6), 498-514.

Atuahene-Gima, K., \& Michael, K. (1998). A Contingency Analysis of the Impact of Salesperson's Effort on Satisfaction and Performance in Selling New Products. European Journal of Marketing, 32 (9/10), 904921.

Baker, W. E., \& Sinkula, J. M. (1999). The synergistic effect of market orientation and learning orientation on organizational performance. Journal of the Academy of Marketing Science, 27 (4), 411-427.

Baum, C. F., Schaffer, M. E. \& S. Stillman (2007), "Enhanced routines for instrumental variables/generalized method of moments estimation and testing," The Stata Journal, 7(4), 465-506.

Beuk, F., Malter, A.J., Spanjol, J., \& Cocco, J. (2014). Financial Incentives and Salesperson Time Orientation in New Product Launch. Journal of Product Innovation Management, 31(4), 647-663. 
Brown, S. P., \& Peterson, R. A. (1994). The effect of effort on sales performance and job satisfaction. Journal of Marketing, 58 (2), 70-80.

Castaño, R., Sujan, M., Kacker, M., \& Sujan, H. (2008). Managing consumer uncertainty in the adoption of new products: Temporal distance and mental simulation. Journal of Marketing Research, 45 (3), 320336.

Chandy, R. K., Tellis, G. J., Maclnnis, D. J., \& Thaivanich, P (2001). What to say when: Advertising appeals in evolving markets. Journal of Marketing Research, 38 (4), 399-414.

Collier, J.E. \& Bienstock, C.C. (2007). An analysis of how nonresponse error is assessed in academic marketing research. Marketing Theory, 7(2), 163-183

Cooper, R. G., \& Kleinschmidt, E. J. (1987). New products: What separates winners from losers? Journal of Product Innovation Management, 4 (3), 169-184.

De Luca, L. M., \& Atuahene-Gima, K. (2007). Market knowledge dimensions and cross-functional collaboration: Examining the different routes to product innovation performance. Journal of Marketing, 71 (1), 95-112.

Dowling, G. R. \& Staelin, R. (1994). A Model of Perceived Risk and Intended Risk-Handling Activity. Journal of Consumer Research, 21 (1), 119-134.

Drechsler, W., Natter, M., \& Leeflang, P.H. (2013). Improving Marketing's Contribution to New Product Development. Journal of Product Innovation Management, 30(2), 298-315.

Ernst, H., Hoyer, W. D., \& Rübsaamen, C. (2010). Sales, marketing, and research-and-development cooperation across new product development stages: Implications for success. Journal of Marketing, 74 (5), 80-92.

Felin, T., \& Hesterly, W. S. (2007). The knowledge-based view, nested heterogeneity, and new value creation: Philosophical considerations on the locus of knowledge. Academy of Management Review, 32 (1), 195-218.

Fornell, C. \& Larcker, D. F. (1981). Evaluating structural equation models with unobservable variables and measurement error. Journal of Marketing Research, 18 (1), 39-50.

Frenzen, H., Hansen, A.-K., Krafft, M., Mantrala, M. K., \& Schmidt, S. (2010). Delegation of pricing authority to the sales force: An agency-theoretic perspective of its determinants and impact on performance. International Journal of Research in Marketing, 27, 58-68.

Gatignon, H., \& Xuereb, J. M. (1997). Strategic orientation of the firm and new product performance. Journal of Marketing Research, 34 (1), 77-90. 
Golden, B. R. (1997). Further remarks on retrospective accounts in organizational and strategic management research. Academy of Management Journal, 40 (5), 1243-1252.

Grant, R. M. (1996a). Toward a knowledge-based theory of the firm. Strategic Management Journal, 17 (Winter Special Issue), 109-122.

Grant, R. M (1996b). Prospering in Dynamically-Competitive Environments: Organizational Capability as Knowledge Integration, Organization Science, 7 (4), 375-387.

Gruner, K. E., \& Homburg, C. (2000). Does customer interaction enhance new product success? Journal of Business Research, 49 (1), 1-14.

Hausman, J. A. (1978). Specification tests in econometrics. Econometrica, 46(6), 1251-1271.

Heckman, J. J. (1976). The common structure of statistical models of truncation, sample selection and limited dependent variables and a simple estimator for such models. Annals of Economic and Social Measurement, 5(4), 475-492.

Heckman, J. J. (1979). Sample selection bias as a specification error. Econometrica: Journal of the econometric society, 153-161.

Henard, D. H., \& Szymanski, D. M. (2001). Why some new products are more successful than others? Journal of Marketing Research, 28 (3), 362-375.

Hoeffler, S. (2003). Measuring preferences for really new products. Journal of Marketing Research, 40 (4), 406-420.

Homburg, C., Vomberg, A. Enke, M., and Grimm P.H. (2015). The loss of the marketing department's influence: is it really happening? And why worry? Journal of the Academy of Marketing Science. 43, 1-13.

Hultink, E. J., \& Atuahene-Gima, K. (2000). The effect of sales force adoption on new product selling performance. Journal of Product Innovation Management, 17 (6), 435-450.

Hultink, E. J., Talke, K., Griffin, A., \& Veldhuizen, E. (2011). Market information processing in new product development: The importance of process interdependency and data quality. IEEE Transactions on Engineering Management, 58 (2), 199-211.

Jaworski, B. J., \& Kohli, A. K. (1991). Supervisory Feedback: Alternative types and their impact on salespeople's performance and satisfaction. Journal of Marketing Research, 28 (2), 190-201.

Jaworski, B. J., \& Kohli, A. K. (1993). Market orientation: Antecedents and consequences. Journal of Marketing, 57 (3), 53-70.

Kim, J., \& Wilemon, D. (2002). Focusing the fuzzy front-end in new product development. $R \& D$ Management, 32 (4), 269-279. 
Kuester, S. and Rauch, A. (2016). A job demands-resources perspective on salespersons' market intelligence activities in new product development. Journal of Personal Selling \& Sales Management, 36 (1), 19-39.

Kumar, K., Subramanian, R., \& Yauger, C. (1998). Examining the market orientation-performance relationship: A context-specific study. Journal of Management, 24 (2), 201-233.

Le Bon, J., \& Merunka, D. (2006). The impact of individual and managerial factors on salespeople's contribution to marketing intelligence activities. International Journal of Research in Marketing, 23 (4), 395408.

Lee, Y., \& O'Connor, G. C. (2003). The impact of communication strategy on launching new products: The moderating role of product innovativeness. Journal of Product Innovation Management, 20 (1), 4-21.

Li, T., \& Calantone, R. J. (1998). The impact of market knowledge competence on new product advantage: Conceptualization and empirical examination. Journal of Marketing, 62 (4), 13-29.

Liao, H., \& Chuang, A. (2004). A multilevel investigation of factors influencing employee service performance and customer outcomes. Academy of Management Journal, 47 (1), 41-58.

Lindell, M. K., \& Whitney, D. J. (2001). Accounting for common method variance in cross-sectional research designs. Journal of Applied Psychology, 86 (1), 114-121.

Maidique, M. A., \& Zirger, B. J. (1983). A study of success and failure in product innovation: The case of the U.S. electronics industry. IEEE Transactions on Engineering Management, 31 (4), 192-203.

Maltz, E., \& Kohli, A. K. (1996). Market intelligence dissemination across functional boundaries. Journal of Marketing Research, 33 (1), 47-61.

Menguc, B., Auh, S., \& Kim, Y. C. (2011). Salespeople's knowledge sharing behaviors with coworkers outside the sales unit. Journal of Personal Selling and Sales Management, 31, 103-122.

Miao, C. F., \& Evans, K. R. (2012). Effects of formal sales control systems: A combinatory perspective. International Journal of Research in Marketing, 29 (2), 181-191.

Montaguti, E., Kuester, S., \& Robertson, T. S. (2002). Entry strategy for radical product innovation: A conceptual model and propositional inventory. International Journal of Research in Marketing. 19 (1), 21-42.

Olson, E. M., Walker, O. C., Ruekert, R. W., \& Banner, J. M. (2001). Patterns of cooperation during new product development among marketing, Operations and R\&D: Implications for project performance. Journal of Product Innovation Management, 18 (4), 258-271. 
Ozkaya, H. E., Droge, C., Hult, G. T., Calantone, R., \& Ozkaya E. (2015). Market orientation, knowledge competence, and innovation. International Journal of Research in Marketing, 32 (3) (Special Issue), 309-318.

Pass, M. W., Evans, K. R., \& Schlacter, J. L. (2004). Sales force involvement in CRM information systems: Participation, support, and focus. Journal of Personal Selling \& Safes Management, 24 (3), 229-234.

Podsakoff, P. M., MacKenzie, S. B., Lee, J. Y., \& Podsakoff, N. P. (2003). Common method biases in behavioral research: A critical review of the literature and recommended remedies. Journal of Applied Psychology, 88 (5), 879-903.

Preacher, K. J., \& Hayes, A. F. (2008). Asymptotic and resampling strategies for assessing and comparing indirect effects in multiple mediator models. Behavior Research Methods, 40 (3), 879-891.

Puhani, P. (2000). The Heckman correction for sample selection and its critique. Journal of economic surveys, 14(1), 53-68.

Rogers, E. M. (2003). Diffusion of innovations. New York: The Free Press.

Schmitz. C. (2013). Group influences of selling teams on industrial salespeople's cross-selling behavior. Journal of the Academy of Marketing Science. 41 (1), 55-72.

Scott, S. G., \& Bruce, R. A. (1994). Determinants of innovative behavior: A path model of individual innovation in the workplace. Academy of Management Journal, 37 (3), 580-607.

Sethi, R., \& Iqbal, Z. (2008). Stage-gate controls, learning failure, and adverse effect on novel new products. Journal of Marketing, 72(1), 118-134.

Sharma, A., \& Lambert, D. M. (1994). How accurate are salespersons' perceptions of their customers? Industrial Marketing Management, 23 (4), 357-365.

Smith, D. C., \& Park, C. W. (1992). The effects of brand extensions on market share and advertising efficiency. Journal of Marketing Research, 29 (3), 296-313.

Song, M. E., \& Parry, M. E. (1997). The determinants of Japanese new product successes. Journal of Marketing Research, 34 (1), 64-76.

Spiller, S. A., Fitzsimons, G. J., Lynch Jr, J. G., and G. H. McClelland (2013), "Spotlights, floodlights, and the magic number zero: Simple effects tests in moderated regression," Journal of Marketing Research, 50(2), 277-288.

Steenkamp, J. B. \& Baumgartner H. (1998). Assessing Measurement Invariance in Cross-National Consumer Research. Journal of Consumer Research, 25 (1), 78-107. 
Steenkamp, J. B. E., and H. Baumgartner (2000). On the use of structural equation models for marketing modeling. International Journal of Research in Marketing, 17(2), 195-202.

Stine, R. A. (1995). Graphical interpretation of variance inflation factors. The American Statistician, 49 (1), 53-56.

Thietart, R. A., \& Vivas, R. (1981). Strategic intelligence activity: The management of the sales force as a source of strategic information. Strategic Management Journal, 2 (1), 15-25.

Troy, L. C., Hirunyawipada, T., \& Paswan, A. K. (2008). Cross-functional integration and new product success: An empirical investigation of the findings. Journal of Marketing, 72 (6), 132-146.

Veldhuizen, E., Hultink, E. J., \& Griffin, A. (2006). Modeling market information processing in new product development: An empirical analysis. Journal of Engineering \& Technology Management, 23 (4), 353373.

Veryzer, R. (1998). Key factors affecting customer evaluation of discontinuous new products. The Journal of Product Innovation Management, 15 (2), 136-150.

Vroom, V. H. (1964). Work and motivation. New York: Wiley.

Wei, Y., \& Morgan, N. A. (2004). Supportiveness of organizational climate, market orientation, and new product performance in Chinese firms. Journal of Product Innovation Management, 21 (6), 375-388.

Wieseke, J., Homburg, C., \& Lee, N. (2008). Understanding the adoption of new brands through salespeople: A multilevel framework. Journal of the Academy of Marketing Science, 36 (2), 278-291.

Wooldridge, J. (2012), Introductory econometrics: A modern approach. Cengage Learning.

Wotruba, T. R., \& Rochford, L. (1995). The impact of new product introductions on sales management strategy. Journal of Personal Selling \& Safes Management, 15 (1), 35-51.

Wotruba, T., Macfie, J. \& Colletti, J. (1991). Effective Sales Force Recognition Programs. Industrial Marketing Management. 20(1), 9-15.

Zahay, D., Griffin, A., \& Fredericks, E. (2004). Sources, uses, and forms of data in the new product development process. Industrial Marketing Management, 33 (7), 657-666.

Zimmer, J. C., Henry, R. M., \& Butler, B. S. (2007). Determinants of the use of relational and nonrelational information sources. Journal of Management Information Systems, 24 (3), 297-331. 
Appendix Results of confirmatory factor analysis

\begin{tabular}{lcc}
\hline Constructs and items & Loadings & t-values \\
\hline $\begin{array}{l}\text { Sales force integration ( } \mathrm{a}=.912 ; \mathrm{CR}=.914 ; \mathrm{AVE}=.728) \\
\text { When developing the new product, }\end{array}$ & & \\
$\quad$...the integration of market information from the sales force was intense. & $.761^{\mathrm{a}}$ & - \\
$\quad \begin{array}{l}\text {...sales force insights with regard to market trends and developments were } \\
\text { strongly considered. }\end{array}$ & .876 & 13.711 \\
$\begin{array}{l}\text {... we paid very close attention to the market information provided by our sales } \\
\text { force. }\end{array}$ & .864 & 13.501 \\
$\quad \begin{array}{l}\text {...sales force intelligence with regard to market developments was frequently } \\
\text { considered. }\end{array}$ & .906 & 14.209 \\
\hline New product advantages $(\alpha=917 \cdot \mathrm{CR}=918 \cdot \mathrm{AVE}=691)$ & & \\
\hline
\end{tabular}

New product advantages ( $\alpha=.917 ; \mathrm{CR}=.918 ; \mathrm{AVE}=.691$ )

According to customers, the new product

...offered unique benefits that were not found in competing products.

.... was clearly superior to competing products.

$.861 \quad 15.540$

$\begin{array}{lll}\text {....offered more value for its money than competing products. } & .822 & 14.476\end{array}$

$\begin{array}{lll}\text {....solved a problem they had with competing products. } & .772 & 13.193\end{array}$

$\begin{array}{llll}\text {...offered performance that was superior to that of competing products. } & .864 & 15.608\end{array}$

Sales force commitment $(\alpha=.898 ; \mathrm{CR}=.904 ; \mathrm{AVE}=.655)$

Our sales force

...had a positive attitude toward the new product.

$\begin{array}{llll}\text {...felt highly responsible for achieving objectives for the new product. } & .803 & 11.859\end{array}$

$\begin{array}{lll}\text {.... showed a strong commitment toward the new product. } & .850 & 12.591\end{array}$

$\begin{array}{lll}\text {....felt emotionally attached to the new product. } & .774 & 11.400\end{array}$

$\begin{array}{lll}\text {....strongly believed in the success of the new product. } & .869 & 12.876\end{array}$

Sales force effort ( $\alpha=.928 ; \mathrm{CR}=.929 ; \mathrm{AVE}=.767$ )

Our sales force

... devoted a great deal of effort to the new product.

...spent a significant amount of time on selling the new product.

$.873^{\mathrm{a}} \quad-$

.888

17.975

...showed strong efforts in achieving objectives for the new product as com-

pared with our existing products.

$.869 \quad 17.269$

...worked hard on the success of the new product.

.872

17.368

New product success $(\alpha=.937 ; \mathrm{CR}=.938 ; \mathrm{AVE}=.790)$

The new product met or exceeded its targets in terms of overall success.

The overall success of the new product was satisfactory.

$.874^{\mathrm{a}} \quad-$

The new product succeeded in achieving its main objectives.

.909

19.227

We were pleased with the overall success of the new product.

$.882 \quad 18.095$

Information quality ( $\mathrm{\alpha}=.922 ; \mathrm{CR}=.923 ; \mathrm{AVE}=.750)$

The market information provided by the sales force during

the development process of the new product

....was of high quality.

...was valuable for the development of the new product.

...fully met our requirements with regard to quality.

.877

$-$

....represented a great benefit in the NPD process.

.868

16.784

.861

16.483

16.263 
Appendix (continued)

Constructs and items

Loadings

t-values

Timing (Predevelopment, Development, Commercialization)

In the development process of the new product, market information stemming from the company's sales force was used in the predevelopment stage/ development stage/ commercialization stage ( 1 = "not intensely at all" and 7 = "very intensely").

Sales force feedback ( $\alpha=.878 ; \mathrm{CR}=.879 ; \mathrm{AVE}=.708$ )

Our sales force

.... was well-informed about the integration of its market information in the development process of the new product.

...knew in how far its market insights were accounted for when developing the new product.

...received feedback on the usage of its market knowledge in the scope of the NPD process.

$.890^{a}$

.831

14.035

.801

13.539

Sales force recognition ( $\alpha=.906 ; \mathrm{CR}=.911 ; \mathrm{AVE}=.774)$

Salespeople whose market information was integrated in the development process of the new product...

....were congratulated.

.... were thanked.

$.968^{a}$

....were honored.

.825

Innovation degree

(1)

(2)

(3)

Imitation of Reposi- Product

competitive tioning

products

line

extension

(4)

(5)

(6)

(7)

Modifi- New-to- New-to- New-to-

cation

the- the- the-

company industry world

product product product

Competitive intensity ( $\alpha=.820 ; C R=.826 ; A V E=.615$ )

Competition in our industry is intense.

One hears of a new competitive move almost every day.

Our competitors are strong and formidable.

.774

$-$

9.673

Marketing Integration ( $\alpha=.912 ; C R=.914 ; A V E=.726$ )

When developing the new product,

...the integration of market information from the marketing department was intense.

...marketing insights with regard to market trends and developments were

strongly considered.

.884

9.554

....we paid very close attention to the market information provided by our marketing function.

$.853^{a}$

.905

10.441

...the intelligence of marketing with regard to market developments was frequently considered.

$.906 \quad 10.665$

$.899 \quad 10.460$ 
Customer Service Integration ( $\alpha=.911 ; C R=.912 ; A V E=.723$ )

When developing the new product, ...the integration of market information from the customer service department was intense.

...customer service insights with regard to market trends and developments were strongly considered.

...we paid very close attention to the market information provided by our customer service function.

...the intelligence of customer service with regard to market developments was frequently considered.

$a=$ Cronbach' alpha; CR = Composite reliability; AVE = Average variance extracted

a) The item was fixed to 1 to set the scale. 
The catbird seat of the sales force:

How sales force integration leads to new product success

Sabine Kuester

Christian Homburg

Andreas Hildesheim

Web Appendix 
Table A1 Validation of model with additional samples (A: product-level data+; B: company-level data)

\begin{tabular}{|c|c|c|c|c|}
\hline \multicolumn{5}{|c|}{ A: Product-level data } \\
\hline Hypothesis & Independent variable & Dependent variable & Beta & $t$-value \\
\hline $\mathrm{H} 1 \mathrm{a}$ & Sales force integration & New product advantages ${ }^{a}$ & $.582^{* * *}$ & 5.839 \\
\hline $\mathrm{H} 1 \mathrm{~b}$ & New product advantages & New product success ${ }^{b}$ & $.466^{* * *}$ & 3.305 \\
\hline $\mathrm{H} 2 \mathrm{a}$ & Sales force integration & Sales force new product adoptionc & $.596^{\star \star *}$ & 7.221 \\
\hline $\mathrm{H} 2 \mathrm{~b}$ & Sales force new product adoption & New product success & $.311^{\star \star \star}$ & 2.429 \\
\hline $\mathrm{H} 3$ & New product advantages & Sales force new product adoption & $.423^{* * *}$ & 5.176 \\
\hline Hypothesis & Moderator variable & Dependent variable & Beta & t-value \\
\hline$\overline{\mathrm{H} 4}$ & Sales force integration $\mathrm{x}$ Information quality & New product advantages & $.119^{* \star}$ & 1.667 \\
\hline \multirow[t]{3}{*}{ H5 } & Sales force integration x Timing (Predevelopment) & New product advantages & $.231^{* * *}$ & 3.204 \\
\hline & Sales force integration $\mathrm{x}$ Timing (Development) & New product advantages & .008 & .106 \\
\hline & Sales force integration x Timing (Commercialization) & New product advantages & $-.122^{* *}$ & 1.693 \\
\hline H6 & Sales force integration $x$ Sales force feedback & Sales force new product adoption & $.099^{*}$ & 1.498 \\
\hline $\mathrm{H} 7$ & Sales force integration $\mathrm{x}$ Sales force recognition & Sales force new product adoption & $.127^{\star *}$ & 1.767 \\
\hline H8 & Sales force new product adoption x Innovation degree & New product success & .071 & 1.100 \\
\hline H9 & Sales force new product adoption $x$ Competitive intensity & New product success & $.083^{*}$ & 1.302 \\
\hline
\end{tabular}

${ }^{a R^{2}}=.443 ; \mathrm{bR}^{2}=.516 ; \mathrm{CR} \mathrm{R}^{2}=.825$

$\mathrm{X}^{2} / \mathrm{df}=1.43 ; \mathrm{RMSEA}=.060 ; \mathrm{IFI}=.95 ; \mathrm{CFI}=.95 ; \mathrm{TLI}=.94 ; \mathrm{NFI}=.86$

${ }^{* * *} p<.01,{ }^{*} p<.05,{ }^{*} p<.1 ; n_{2}=121$ (US only)

+) We also combined the main sample $(n=219)$ and this product-level validation sample $(n=121)$ and conducted split-half analyses. The results remain robust in the resulting samples in terms of magnitude and significance. 
Table A1 Validation of model with additional samples (A: product-level data+; B: company-level data) (continued)

\begin{tabular}{|c|c|c|c|c|}
\hline \multicolumn{5}{|c|}{ B: Company-level data ${ }^{++}$) } \\
\hline Hypothesis & Independent variable & Dependent variable & Beta & $t$-value \\
\hline$\overline{\mathrm{H} 1 \mathrm{a}}$ & Sales force integration & New product advantages ${ }^{a}$ & $.482^{\star \star \star}$ & 7.317 \\
\hline $\mathrm{H} 1 \mathrm{~b}$ & New product advantages & New product success ${ }^{b}$ & $.538^{\star \star \star}$ & 7.237 \\
\hline $\mathrm{H} 2 \mathrm{a}$ & Sales force integration & Sales force new product adoption ${ }^{c}$ & $.453^{* * *}$ & 9.014 \\
\hline $\mathrm{H} 2 \mathrm{~b}$ & Sales force new product adoption & New product success & $.253^{* * *}$ & 3.598 \\
\hline H3 & New product advantages & Sales force new product adoption & $.498^{* * *}$ & 9.514 \\
\hline Hypothesis & Moderator variable & Dependent variable & Beta & t-value \\
\hline$\overline{\mathrm{H} 4}$ & Sales force integration $\mathrm{x}$ Information quality & New product advantages & $.166^{\star \star \star}$ & 3.035 \\
\hline \multirow[t]{3}{*}{ H5 } & Sales force integration x Timing (Predevelopment) & New product advantages & $.092^{* *}$ & 2.102 \\
\hline & Sales force integration x Timing (Development) & New product advantages & .019 & .390 \\
\hline & Sales force integration x Timing (Commercialization) & New product advantages & $-.118^{* \star *}$ & 2.383 \\
\hline H6 & Sales force integration $x$ Sales force feedback & Sales force new product adoption & $.218^{* \star *}$ & 4.772 \\
\hline $\mathrm{H} 7$ & Sales force integration $x$ Sales force recognition & Sales force new product adoption & $.240^{\star * \star}$ & 5.408 \\
\hline H8 & Sales force new product adoption $\mathrm{x}$ Innovation degree & New product success & $.124^{* * *}$ & 2.858 \\
\hline H9 & Sales force new product adoption $\mathrm{x}$ Competitive intensity & New product success & .027 & .606 \\
\hline
\end{tabular}

${ }^{a} R^{2}=.219 ;{ }^{b} R^{2}=.563 ;{ }^{c} R^{2}=.663$

$\mathrm{X}^{2} / \mathrm{df}=1.55 ; \mathrm{RMSEA}=.045 ; \mathrm{IFI}=.97 ; \mathrm{CFI}=.97 ; \mathrm{TLI}=.96 ; \mathrm{NFI}=.93$

${ }^{* * *} p<.01,{ }^{* *} p<.05,{ }^{*} p<.1 ; n_{3}=269$

${ }^{++}$) Due to uneven sample sizes in the different country settings, assessment of measurement invariance via multi-sample confirmatory factor analysis (Steenkamp and Baumgartner 1998) was not feasible. To check whether measures can be used cross-nationally, we excluded the responses from Australia and the UK and re-ran all analyses with the US-sample only. Results were robust in magnitude and significance levels against this change so that we conclude that cross-national invariance is given in our study. 
Table A2 Validation of model with objective success measures

\begin{tabular}{|c|c|c|c|c|}
\hline \multicolumn{5}{|c|}{ Sales volume / Total asset value as objective success measures } \\
\hline Hypothesis & Independent variable & Dependent variable & Beta & $t$-value \\
\hline$\overline{\mathrm{H} 1 \mathrm{a}}$ & Sales force integration & New product advantages ${ }^{a}$ & $.488^{\star \star *}$ & 6.694 \\
\hline $\mathrm{H} 1 \mathrm{~b}$ & New product advantages & Sales volume $e^{b}$ Total asset value & $.506^{\star *} / .754^{\star \star \star}$ & $2.025 / 3.266$ \\
\hline $\mathrm{H} 2 \mathrm{a}$ & Sales force integration & Sales force new product adoption ${ }^{d}$ & $.609^{* * *}$ & 11.106 \\
\hline $\mathrm{H} 2 \mathrm{~b}$ & Sales force new product adoption & Sales volume / Total asset value & $.360^{*} / .501^{* *}$ & $1.442 / 2.188$ \\
\hline H3 & New product advantages & Sales force new product adoption & $.408^{* * *}$ & 7.532 \\
\hline Hypothesis & Independent variable & Dependent variable & Beta & t-value \\
\hline$\overline{\mathrm{H} 4}$ & Sales force integration $\mathrm{x}$ Information quality & New product advantages & $.208^{* * *}$ & 3.735 \\
\hline \multirow[t]{3}{*}{$\mathrm{H} 5$} & Sales force integration x Timing (Predevelopment) & New product advantages & $.104^{* *}$ & 2.018 \\
\hline & Sales force integration x Timing (Development) & New product advantages & .015 & .298 \\
\hline & Sales force integration x Timing (Commercialization) & New product advantages & $-.194^{* * *}$ & 3.841 \\
\hline $\mathrm{H} 6$ & Sales force integration x Sales force feedback & Sales force new product adoption & $.111^{* *}$ & 2.226 \\
\hline $\mathrm{H} 7$ & Sales force integration $\mathrm{x}$ Sales force recognition & Sales force new product adoption & $.146^{\star \star *}$ & 3.108 \\
\hline $\mathrm{H} 8$ & Sales force new product adoption $\mathrm{x}$ Innovation degree & Sales volume / Total asset value & $.154^{*} / .268^{* \star *}$ & 1.352 / 2.879 \\
\hline H9 & $\begin{array}{l}\text { Sales force new product adoption x Competitive inten- } \\
\text { sity }\end{array}$ & Sales volume / Total asset value & $.292^{\star * \star} / .173^{* \star}$ & $2.340 / 1.979$ \\
\hline
\end{tabular}

$\mathrm{aR}^{2}=.234 ;{ }^{b} \mathrm{R}^{2}=.130 ; \mathrm{cR}^{2}=.290 ; \mathrm{d}^{2}=.776$

$\mathrm{X}^{2} / \mathrm{df}=2.56 ; \mathrm{RMSEA}=.085 ; \mathrm{IFI}=.93 ; \mathrm{CFI}=.93 ; \mathrm{TLI}=.90 ; \mathrm{NFI}=.89$

${ }^{* * *} p<.01,{ }^{* *} p<.05,{ }^{*} p<.1 ; \mathrm{n}_{4}=4$ 